\title{
Utilization of Coir Pith for the Stabilization of Black Cotton Soil
}

\author{
Ch Vineel, T V ViswaTeja, M Usha Rani, B Vineeth, B Vamsi Krishna
}

\begin{abstract}
Expansive soil deposits mostly appear in arid and semi-arid areas of the world and they pose severe difficulties to engineering constructions as they possess higher tendency to heave in the course of moist season and shrink at summer season. Construction in such highly expansive strata can be done by adopting ground modification techniques like soil stabilization, Vertical drains, inducing reinforcement in to soil etc., On the other hand with rapid industrial growth more quantity of industrial waste will be generated which will trigger several environmental issues when it is dumped in to environment. Utilization of industrial waste in construction industry without compromising in strength criteria is the best possible option for the engineers as the waste is used as construction material there will be no need for dumping yards, biodiversities can be protected, strength properties of the soil can be enhanced and hydraulic properties can also be modified by treating soil with industrial wastes. As the river sand can be partially replaced by some of the industrial wastes requirement for natural sand can be reduced which will not only economise the construction cost but also preserves the natural resources. The present study was carried out to assess the behaviour of coir pith treated black cotton soils. Due to increase in the natural fibres in many industries the waste produced from the coir industry is increasing, if proper care is not taken these waste may create severe effects on environment .To avoid disposal of this waste directly into environment it is better to use the waste in construction industry is a better option. But before adopting such practices proper studies are to be done to check whether these materials are suitable for treating the soils are not .In the present study by adding various proportions of coir pith Swell, strength characteristics of soil where compared for obtaining the optimum Replacement percentage.
\end{abstract}

Keywords: Black Cotton Soil, Coir pith, Soil Stabilization, Strength characteristics.

\section{INTRODUCTION}

Majority area in India is covered by Black cotton soil. Mostly at Central, western and southern states of India we

Revised Manuscript Received on May 27, 2020.

* Correspondence Author

Mr. Ch Vineel*, Civil Engineering Department, ANITS(A), Visakhapatnam, India. Email: vineel.ce@anits.edu.in

Mr. T V Viswa Teja, Civil Engineering Department, ANITS(A), Visakhapatnam, India. Email: teja.ce@anits.edu.in

Ms. M Usha Rani, Civil Engineering Department, ANITS(A), Visakhapatnam, India. Email: musharani.15.ce@anits.edu.in

Mr. B Vineeth, Civil Engineering Department, ANITS(A), Visakhapatnam, India. Email: bvineeth.15.ce@anits.edu.in

Mr. B Vamsi Krishna, Civil Engineering Department, ANITS(A), Visakhapatnam, India. Email: bvamsikrishna.15.ce@anits.edu.in

(c) The Authors. Published by Blue Eyes Intelligence Engineering and Sciences Publication (BEIESP). This is an open access article under the CC BY-NC-ND license (http://creativecommons.org/licenses/by-nc-nd/4.0/) can found deposits of black cotton soils. These soils undergo volumetric changes when there is a change in moisture content in it which poses severe problems to structures constructed over them. Therefore, stabilization of such soils is needed to be done. Many studies were conducted to modify the locally available problematic soil by using natural, artificial/synthetic fibers, agricultural and industrial wastes to stabilize the soils. The utilization of wastes for treating the soils not only improves the strength but also it reduces the environmental effects caused due to open dumping of these wastes. Among the world India produces largest quantity of coir. In the coir producing industry the fibres are extracted from the coconut husk, during this process a by product is obtained which is known as Coir pith. It is estimated that about two tons of coir pith is produced for every ton of fibre extracted. As the coir pith is lite in weight it will cause environmental nuisance if it is disposed on open site. To avoid such problems instead of dumping, it is used for treating the black cotton soils. It was found that coir pith has great capacity of moisture absorption so when it is treated with soil it will absorb the moisture hence reduces the volume changes in the soil.

\section{REVIEW OF LITERATURE}

Narendra Goud, G., et. al., (2018) has investigated the properties of black cotton soil treated with various proportions of coir pith and lime. With increment in coir pith content the Maximum dry density got decreased and optimum moisture content increased. Addition of lime made the black cotton soil suitable for sub grade by reducing its swell index value. Combined effect of lime and coir pith causes a significant increase in the CBR value.

Arthi, P.D., et. al., (2017) has studied the enhancement in the properties of expansive soil with addition of Coir Pith in various proportions. The atterberg limits, OMC, MDD and UCS values are obtained with various proportions of coir pith replacements. $2 \% \& 3 \%$ Addition of coir pith showed reduction in plasticity index and increment in the MDD, UCS values of black cotton soil. California Bearing Ratio strength increased with increment in the coir pith percentage.

Leemapeter et. al., (2016) in his study he found that coir pith can be effectively used for enhancing the engineering properties of subgrade black cotton soil. He observed an increment of $192 \%$ and $335 \%$ in the CBR value with an addition of $2 \%$ coir pith and $0.6 \%$ of short coir fiber

Stuti Maruya et.al., (2015) has investigated the index and engineering properties of black cotton soil treated with coir pith. Various proportions of coir pith and lime are mixed with black cotton soils to reduce the swelling and shrinkage behavior of soil. CBR and UCS tests were conducted under soaked and unsoaked

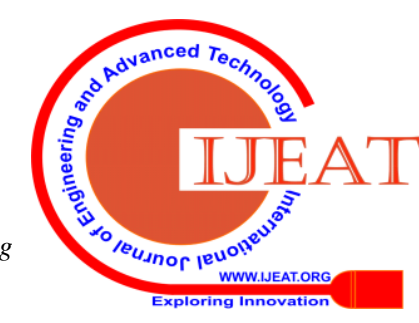


conditions. From the study he observed that both CBR and UCS strength values increased when soil is mixed with $1 \%$ of coir pith.

Shruthi Johnson. et., al., (2016) has investigated that with an addition of $12 \%$ of there is a decrement in the MDD value where as they found an increment of OMC values at the same percentage of coir pith. The density of the coir pith soil mixture reduces with an increment in the coir pith percentage due to coir pith low dense nature. As coir pith absorbs more quantity of water its OMC will increase with an increment in coir pith percentage in soil but it will exhibit a good binding property with clay. Reduction in swell pressure is observed with an increment in the percentage of coir pith in soil

Gayatri. S et., al., has investigated that when the expansive soil is treated with coir pith the swelling characteristics decreased from $22.22 \%$ to $8.33 \%$ at $4 \%$ of coir pith and $4.85 \%$ at $10 \%$ of coir pith. Addition of $4 \%$ of coir pith gives the highest unconfined compressive strength of $0.206 \mathrm{~N} / \mathrm{mm}^{2}$. Addition of $6 \%$ of coir pith gives the highest MDD of $1.43 \mathrm{gm} / \mathrm{cm}^{3}$ and OMC of $17.5 \%$.

Raziya banu et.al., (2015) has investigated the variations of the engineering properties of black cotton soil with various proportions of coir pith. They found decrement in the liquid limit with an increase in coir pith percentage. They also found that there is an increment in the MDD and UCS values upto $0.2 \%$ of coir pith. After $0.2 \%$ coir pith further addition of coir pith reduced the MDD. As UCS characteristics are considered the strength increased with the increase of curing days upto $0.2 \%$ coir pith when compared to untreated BC soil.

\section{EXPERIMENTAL WORK}

The properties of black cotton soil and coir pith are determined by performing various experiments in geotechnical engineering lab. The properties determined are presented in Table I.

Table I Properties of black cotton soil and Coir Pith

\begin{tabular}{|c|c|c|}
\hline Engineering properties & Soil & Coir Pith \\
\hline Specific Gravity (G) & 2.64 & 0.67 \\
\hline Grain Size distribution & & \\
a) Gravel & 0 & - \\
b) Sand & $93.49 \%$ & - \\
c) Percentage of Fines & $6.51 \%$ & - \\
d) C & 5.0 & 4.25 \\
e) C $_{\mathrm{c}}$ & 1.2 & 0.94 \\
\hline Plasticity Characteristics & & \\
a) Liquid limit & $51.90 \%$ & $\mathrm{NP}$ \\
b) Plastic limit & $26.16 \%$ & $\mathrm{NP}$ \\
c) Shrinkage Limit & $12.34 \%$ & $\mathrm{NP}$ \\
\hline IS classification & $\mathrm{CH}$ & $\mathrm{SP}$ \\
\hline Compaction Characteristics & & \\
OMC (\%) & 24.2 & 25.73 \\
MDD (g/cm ${ }^{3}$ ) & 1.485 & 0.251 \\
\hline CBR (\%) & $3.89 \%$ & - \\
& & \\
\hline
\end{tabular}

U.C.S $\left(\mathrm{kN} / \mathrm{m}^{2}\right)$

60.81

Comparison of Strength Properties of Black Cotton soil treated with various proportions of Coir pith

Coir pith of $1.0 \%, 1.5 \%$ and $2 \%$ are mixed with black cotton soil and various laboratory experiments like Modified Proctor test, Swell Pressure test, Unconfined Compressive strength test, California Bearing Ratio Test are performed. The results obtained are presented in Table 2.

Table II Comparison of Properties of Black Cotton Soil treated with various proportions of Coir pith

\begin{tabular}{|l|c|c|c|}
\hline \multicolumn{1}{|c|}{ Experiment } & $\begin{array}{c}\mathbf{1 . 5} \text { \% } \\
\text { Coir Pith }\end{array}$ & $\begin{array}{c}\mathbf{2 . 0} \text { \% } \\
\text { Coir Pith }\end{array}$ & $\begin{array}{c}\mathbf{2 . 5} \% \\
\text { Coir Pith }\end{array}$ \\
\hline U.C.S (kN/m²) & 74.02 & 95.34 & 65.96 \\
\hline $\begin{array}{l}\text { Swell Pressure } \\
\left(\mathrm{kN} / \mathrm{m}^{2}\right)\end{array}$ & 75.4 & 65.72 & 60.00 \\
\hline C.B.R (\%) & 9.34 & 11.67 & 12.45 \\
\hline OMC (\%) & 25 & 26.39 & 25.45 \\
MDD (g/cm $\left.{ }^{3}\right)$ & 14.40 & 14.08 & 13.76 \\
\hline
\end{tabular}

\section{RESULT AND DISCUSSION}

1.From the compaction test the Maximum Dry Density (MDD) and Optimum Moisture Content (OMC) for Black Cotton Soil and Coir pPith are obtained as $14.80 \mathrm{kN} / \mathrm{m}^{3}, 24.2 \%$, and $2.5 \mathrm{kN} / \mathrm{m}^{3}, 25.73 \%$ respectively. The density of the coir pith replaced soil has decreased with an increment in coir pith. The MDD obtained for $1.5 \%, 2.0 \%, 2.5 \%$ coir pith replaced soil are $14.40 \mathrm{kN} / \mathrm{m}^{3}$, $14.10 \mathrm{kN} / \mathrm{m}^{3}, 13.76 \mathrm{kN} / \mathrm{m}^{3}$.

2.The Unconfined Compressive Strength (UCS) of virgin soil is obtained as $60.81 \mathrm{kN} / \mathrm{m}^{2}$, with the replacement of various proportions of coir pith the UCS Values shown an increment. The percentage increment of UCS for $1.5 \%$, $2.0 \%$, and $2.5 \%$ coir pith replacement are $21.73 \%$, 56.78\%, $8.46 \%$.

3.The Unconfined Compressive Strength (UCS) of virgin soil is obtained as $60.81 \mathrm{kN} / \mathrm{m}^{2}$, with the replacement of various proportions of coir pith the UCS Values shown an increment. The percentage increment of UCS for $1.5 \%$, $2.0 \%$, and $2.5 \%$ coir pith replacement are $21.73 \%$, 56.78\%, $8.46 \%$.

4.At $1.5 \%$ of coir pith the UCS Value obtained as $74.02 \mathrm{kN} / \mathrm{m}^{2}$, with an increase of $0.5 \%$ of coir pith the strength got increased upto $28.80 \%$, where as with an further increase of $0.5 \%$ of coir pith the UCS value decreased by $30.81 \%$.

5.The swell pressure for the virgin soil is obtained as $83 \mathrm{kN} /$ $\mathrm{m}^{2}$.With replacement of various proportions of coir pith the swell pressure has shown decrement of $75.4 \mathrm{kN} / \mathrm{m}^{2}, 65.72$ $\mathrm{kN} / \mathrm{m}^{2}, 59.72 \mathrm{kN} / \mathrm{m}^{2}$. with addition of $0.5 \%$ of coir pith the percentage decrement in Swell Pressure is obtained as $12.83 \%$ whereas with a further increment of $0.5 \%$ it showed an decrement of $10.04 \%$.

6.The CBR value obtained for virgin soil is $3.89 \%$. with replacement of various proportions of coir pith the CBR value also increased. By adding $1.5 \%$ of coir pith the Increment in CBR percentage is obtained as

Published By:

Blue Eyes Intelligence Engineering

\& Sciences Publication

(C) Copvriaht: All riahts reserved.

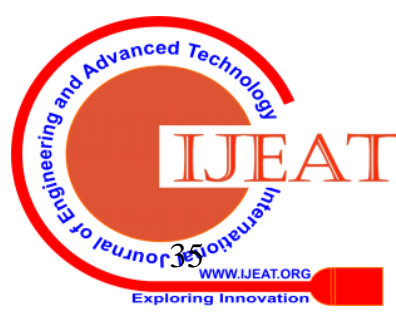


$1.45 \%$ whereas with a further increment of $0.5 \%$ it showed an increment of $2.07 \%$.

\section{CONCLUSION}

The Present work reveals that with the addition of Coir pith the swell and shrinkage behaviour of the black cotton soil can be effectively controlled. The MDD values of the coir pith stabilized soil shown minor decrement which shows there is no much effect on strength of stabilized soil. The decrease in the M.D.D Values are due to reduction in the weight of soil after replacing it with certain proportion of coir pith is due to lesser density of coir pith compared to black cotton soil. The UCC values got increased at $2 \%$ coir pith replacement after that it showed decrement which suggests that with addition of coir pith the Compressive Strength of soil gets modified up to a certain value. In the present study it was observed that the CBR Values shown increment with increase in percentage replacement of coir pith up to $1.5 \%$. From the study it was observed that the coir pith can be utilized for stabilizing the black cotton soils effectively without compromising on strength parameters.

\section{REFERENCES}

1. Arthi, P.D., et.al., (2017) "Stabilization of black cotton soil using coir pith" International research journal of engineering and technology (ISSN:2395-0056) volume Issue 2, February 2017.

2. Jayasree.P.K, et al., (2013). "Influence of Coir Pith on Swelling and Shrinkage Characteristics of Expansive Soil", Proceedings of Indian Geotechnical Conference roorkee.

3. Leemapeter., et. Al., (2016) "laboratory investigation in the improvement of sub grade characteristics of expansive soil stabilized with coir waste" Transportation Research procedia 17(2016) 558-566 TMPDC 2014, 10-12 December 2014.

4. Noorahmed A H., et.al., (2017) "Stabilization of black cotton soil using coir pith and bagasse ash as stabilizer" Angadi Institute of Technology \& Management, Belagavi Project Reference No:39S_BE_1799

5. Pardeshi Arthi G., et.al., (2018) "Stabilization of black cotton soil using coir pith" International journal of modern trends in engineering and research (ISSN:2349-9745) volume 5, Issue 4, April-2018.

6. Raziya Banu., et.al., (2015) "Stabilization of Black Cotton Soil Using Coir Pith "International journal of technology enhancements and emerging engineering research (ISSN 2347-4289) volume 3, Issue 08

7. Sambre Tejashri Ramesh; Prof.Naik U.P. (2016) "Stabilization of Expansive Soil”, ISSN: 2277-3754 ISO 9001:2008 Certified International Journal of Engineering and Innovative Technology (IJEIT) Volume 5, Issue 12, and June 2016.

8. Shreyas.K ., et.al.,(2017) "Stabilization of clayey soil by lime \& coir" Don Bosco Institute of technology, Bangalore, INDIA Institution of Electronics and Telecommunications Engineers,Pune,India ISBM:978-9386171-75-7 ICNPETM-2017.

9. Shurthi Jhonson ., et.al., (2016) " A Study on swell behaviour of Expansive soil Reinforced with saw dust and coir pith and marble dust "International journal of engineering research \& technology(ISSN:2278-0181) volume.5, Isuue09, September 2016

10. Vinod, and Ajitha B. Bhaskar. (2009). "Effective use of coir products in ground improvement", Guntur, INDIA

\section{AUTHORS PROFILE}

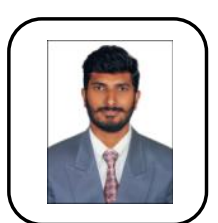

Mr. Ch. Vineel, M.E, (PhD) has 5years 8months work experience as Assistant Professor in the Department of Civil Engineering, ANITS (A), Visakhapatnam, AP, India. He is pursuing his $\mathrm{PhD}$ at Andhra University, Visakhapatnam, AP, India. He published 5 Research papers in various peer reviewed journals.GIT,Geosynthetic Materials, Utilization of coal ashes as Construction material, replacement of fine aggregate with coal ashes in Concrete; GIS are his major areas of interests in Research. He holds a Life Membership in IGS.

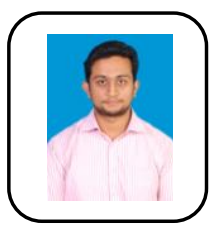

Mr. T V Viswa Teja, M.E., has 5years 7 months of work experience as Assistant. Professor, Civil Engineering, ANITS(A), Visakhapatnam. He has 6 publications in SCOPUS Indexed and Peer Reviewed Journals in the areas of Hybrid Concrete, Geosynthetics, Alternative green energies, Net-Zero Energy Constructions, etc. He is Life Member in IGS, Associate Member in IE(I) and authorized to use the style \& title of Chartered Engineer - CV Division - IE(I).

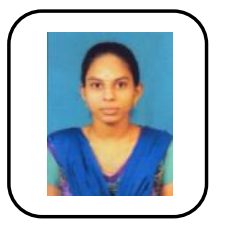

Ms. M. Usha Rani, IV/IV B.Tech Student of Dept. of Civil Engineering, ANITS (A), Visakhapatnam.,A.P,India.

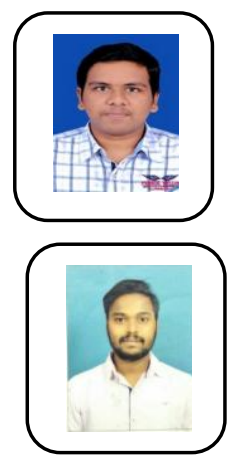

Mr. B. Vineeth, IV/IV B.Tech Student of Dept. of Civil Engineering, ANITS (A), Visakhapatnam.,A.P,India.

Mr. B. Vamsi Krishna, IV/IV B.Tech Student of Dept. of Civil Engineering, ANITS (A), Visakhapatnam.,A.P,India.

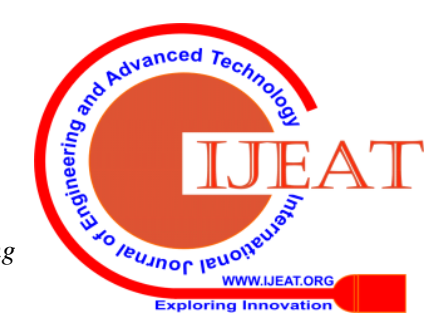

